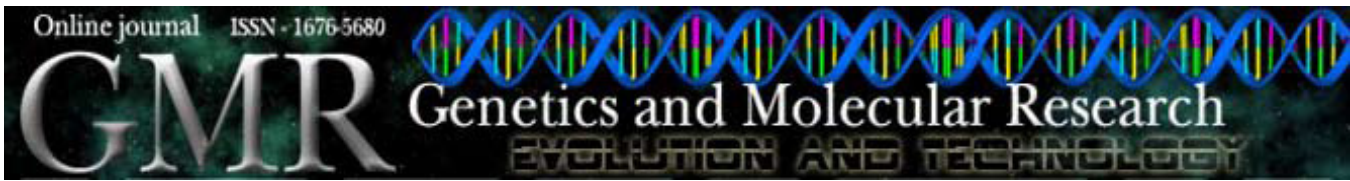

\title{
An optimized preparation method to obtain high-quality RNA from dry sunflower seeds
}

\author{
X.B. $\mathrm{Ma}^{1}$ and J. Yang ${ }^{1,2}$ \\ ${ }^{1}$ School of Life Sciences, China West Normal University, Nanchong, Sichuan, \\ P.R. China \\ ${ }^{2}$ Key Laboratory of Southwest China Wildlife Resources Conservation, \\ Ministry of Education, China West Normal University, Nanchong, Sichuan, \\ P.R. China \\ Corresponding author: J. Yang \\ E-mail: yangjunlz@tom.com
}

Genet. Mol. Res. 10 (1): 160-168 (2011)

Received August 16, 2010

Accepted November 30, 2010

Published February 1, 2011

DOI 10.4238/vol10-1gmr979

\begin{abstract}
In an attempt to isolate high-quality, intact total RNA from sunflower (Helianthus annuus) seeds for investigation of the molecular mechanisms of mutations, we tested various procedures, using kits, including RNAiso Plus, RNAiso Plus+RNAiso-mate for Plant Tissue, Trizol, and the Qi method, but no high-quality total RNA of high integrity was obtained with any of these methods, probably due to the high content of polyphenols, polysaccharides, and secondary metabolites in mature sunflower seeds. Modifications were made to the Qi method. To avoid polyphenol oxidation, frozen dry seeds free of the seedcase were ground in a mortar with an equal amount of PVP30, and the fine ground powder was transferred to an extraction buffer with $2 \%$ PVP30 (w/v), 5\% $\beta$-mercaptoethanol (v/v) and $\mathrm{LiCl}(8 \mathrm{M})$. A sample homogenate was extracted with chloroform prior to acidic phenolchloroform extraction. The total RNA was precipitated with $1 / 4$ volume of $\mathrm{NaAc}$ and 2 volumes of absolute ethanol to prevent contamination by polysaccharides. The yield of total RNA was $29.95 \mu \mathrm{g} / 100 \mathrm{mg}$ husked dry seeds; the ratios of A260/A230 and A260/A280 were 2.44 and 2.09, respectively. Electrophoretic analysis clearly showed $28 \mathrm{~S}$ and
\end{abstract}


$18 \mathrm{~S}$ ribosomal RNA bands. Using the extracted RNA, a fragment of the actin gene was successfully expressed by RT-PCR. This modified protocol is suitable for isolating high-quality total RNA from sunflower seeds for molecular research.

Key words: Sunflower seeds; RNA isolation; PVP; RT-PCR; $\beta$-mercaptoethanol; Ethanol

\section{INTRODUCTION}

Sunflower (Helianthus annuus L.) is the third most important oil crops worldwide. The seeds of this plant are an abundant source of edible vegetable oil, starch, protein, minerals, vitamins, and antioxidants for human nutrition and animal (Alonso et al., 2007; Zavallo et al., 2010; Ruiz-Lopez et al., 2010). Sunflower can be utilized as ornamental plants in addition to its commercial value (Huaiqin et al., 2009). Pure seeds were carried by space flight in recoverable satellite "Shenzhou No. 4" for mutational induction in 2002, and then some plants with mutational characters, including plants with high ornamental values, were screened out from the descendant plants; subsequently they were bred as mutant lines individually. To investigate the molecular mechanism of the mutation, the most effective approach is to clone genes and to research their genetic function. Usually, precondition for gene cloning is to obtain intact, high-quality and quantity RNA.

To our knowledge, there has been no report on total RNA extraction from seeds of sunflower in the literature. We tried to isolate total RNA from their seeds following the handbooks of RNAiso Plus, RNAiso Plus+RNAiso-mate for Plant Tissue and Trizol, or the method reported by Qi et al. (2009), but it is difficult to obtain high-quality RNA, perhaps due to the high levels of lipids, starch, polyphenol, polysaccharide, storage proteins, secondary metabolites, and endogenous RNase in seeds (Salzman et al., 1999; Singh et al., 2003; Azevedo et al., 2003; Li and Trick, 2005; Birtic and Kranner, 2006; Bilgin et al., 2009). According to previous reports (Salzman et al., 1999; Qi et al., 2009; Ghangal et al., 2009; Bilgin et al., 2009), soluble polyvinylpyrrolidone (PVP), $\beta$-mercaptoethanol and absolute ethanol were used to modify the method reported by Qi et al. (2009) for RNA extraction, and high-quality RNA was obtained.

\section{MATERIAL AND METHODS}

Fine sunflower seeds in $\mathrm{SP}_{7}$ generation were selected. After their seedcases were peeled off, the remained parts of the seeds were used for RNA extraction.

\section{Total RNA extraction}

1) Extract total RNA following the direction of RNAiso Plus (TaKaRa, Japan).

2) Isolate total RNA as the handbook of RNAiso Plus+RNAiso-mate for Plant Tissue (TaKaRa).

3) Collect total RNA following the instruction book of Trizol (Bio Basic Inc., Canada).

4) Extract total RNA according to the method reported by Qi et al. (2009).

5) Extract total RNA using the modified method based on Qi et al. (2009) as following: 


\section{Preparation of solution and reagents}

1) Extraction buffer: $8 \mathrm{M} \mathrm{LiCl}, 2 \%(\mathrm{w} / \mathrm{v})$ PVP30, $5 \%$ (v/v) $\beta$-mercaptoethanol.

2) Solubilization buffer: $1.4 \%(\mathrm{w} / \mathrm{v}) \mathrm{SDS}, 0.075 \mathrm{M} \mathrm{NaCl}, 0.025 \mathrm{M}$ EDTA, $2 \%(\mathrm{v} / \mathrm{v})$ $\beta$-mercaptoethanol.

3) Trizol (Bio Basic Inc.).

4) RNA PCR Kit (AMV) Version 3.0, RNAiso Plus and RNAiso-mate for Plant Tissue (TaKaRa).

5) $3 \mathrm{M} \mathrm{NaAc}, \mathrm{pH} 5.2$.

6) Water-saturated acidic phenol, $\mathrm{pH} 4.5$.

7) PVP30, absolute ethanol, chloroform and liquid nitrogen.

\section{Procedure of the total RNA extracted by the modified method}

All centrifugations are at maximum speed at $4{ }^{\circ} \mathrm{C}$ (Eppendorf Centrifuge 5810R, Germany) unless otherwise indicated.

1) $60 \mathrm{mg}$ dry seeds free of seedcase was frozen in liquid nitrogen for a minimum of 20 min up to overnight and ground to fine powder with pestle in the presence of liquid nitrogen adding PVP30.

2) Transfer frozen powder to a $1.5-\mathrm{mL}$ microcentrifuge tube containing $900 \mu \mathrm{L}$ extrac tion buffer, $45 \mu \mathrm{L} \beta$-mercaptoethanol, and different content of ethanol, and then shake vigorously for $5 \mathrm{~min}$ and incubate at $4^{\circ} \mathrm{C}$ overnight.

3) Add $100 \mu \mathrm{L}$ chloroform, mix gently and centrifuge at $5000 \mathrm{rpm}$ for $3 \mathrm{~min}$ at $4{ }^{\circ} \mathrm{C}$ to precipitate for high molecular weight impurities and liquids.

4) Transfer suspension to a new $1.5-\mathrm{mL}$ microcentrifuge and spin for $30 \mathrm{~min}$ at $4{ }^{\circ} \mathrm{C}$.

5) Dissolve pellet in $550 \mu \mathrm{L}$ solubilization buffer, add $550 \mu \mathrm{L}$ chloroform, mix thoroughly and centrifuge for $5 \mathrm{~min}$.

6) Transfer suspension to a new $1.5-\mathrm{mL}$ microcentrifuge tube, add $500 \mu \mathrm{L}$ water-saturated acidic phenol and $300 \mu \mathrm{L}$ chloroform, then mix thoroughly, and spin for $10 \mathrm{~min}$.

7) Transfer suspension to a new $1.5-\mathrm{mL}$ tube, add $100 \mu \mathrm{L} 3 \mathrm{M} \mathrm{NaAc}, \mathrm{pH} 5.2$, and $800 \mu \mathrm{L}$ ethanol, mix well and leave at $-20^{\circ} \mathrm{C}$ for $1 \mathrm{~h}$. Spin for $20 \mathrm{~min}$, wash pellet with $75 \%$ ethanol, air-dry RNA and resuspend in $40 \mu \mathrm{L}$ DEPC-water.

\section{Technical notes}

$\beta$-mercaptoethanol should only be added to the extraction buffer and solubilization buffer prior to use.

\section{RNA assessment}

The absorbance of total RNA in sterilization water free of ion was evaluated at 230, 260, $280 \mathrm{~nm}$ using a UNIC UV-2102C spectrophotometer (China). RNA yield was calculated based on the Beer-Lambert Law, according to which the yield in $\mu \mathrm{g} / \mathrm{mL}$ is 100 -fold of the absorbance at $260 \mathrm{~nm}$ (A260) (Wang and Stegemann, 2009). RNA purity was tested by the ratios of A260/A230 and A260/A280. 


\section{RT-PCR analysis}

For RT-PCR (reverse transcription-polymerase chain reaction), first-strand cDNA was synthesized using the TaKaRa RNA PCR Kit (AMV) Ver. 3.0, in which RT was performed by 10 -min incubation at $30^{\circ} \mathrm{C}, 30$-min incubation at $50^{\circ} \mathrm{C}, 5$-min incubation at $95^{\circ} \mathrm{C}$, and 5 -min incubation at $5^{\circ} \mathrm{C}$. PCR was conducted in a Bio-Rad thermal 580BR3785 cycler following the instruction of the TaKaRa RNA PCR Kit (AMV) Ver. 3.0. The parameters of PCR program were: $94^{\circ} \mathrm{C}$ for $2 \mathrm{~min}, 35$ cycles of $94^{\circ} \mathrm{C}$ for $30 \mathrm{~s}, 47^{\circ} \mathrm{C}$ for $30 \mathrm{~s}$, $72^{\circ} \mathrm{C}$ for $66 \mathrm{~s}$, and a final extension step at $72^{\circ} \mathrm{C}$ for $5 \mathrm{~min}$. A housekeeping gene, actin, was tested using primers as followed: 5'-GTGACAATGGAACAGGAATG-3' (forward, actin), 5'-CACTTCCGGTGGACAATG-3' (reverse, actin).

\section{RESULTS}

\section{Purity, yield of total RNA}

Using the procedures described above or handbooks of kits, total RNA could be extracted from $100 \mathrm{mg}$ seeds of sunflower without seedcases, but the purities and yields of RNA varied depending on different kits used or the modified method using different volumes of absolute ethanol in extraction buffer. As shown in Table 1, the ratios of A260/A230 for the total RNA obtained by RNAiso Plus or Trizol were lower than 2.0, and their ratios of A260/ A280 were less than 1.8, suggesting their impurity. In the Qi method, the total RNA showed high purity with prospected ratios of A260/A230 and A260/A280; however, only low yield of RNA was achieved. Comparatively, the method of RNAiso Plus+RNAiso-mate obtained high purity and yield of total RNA (Table 1).

Table 1. Purity and yield of the total RNA extracted from seeds of sunflower using three kits.

\begin{tabular}{lccc}
\hline Kit & \multicolumn{2}{c}{ Purity } & Yield $(\mu \mathrm{g} / 100 \mathrm{mg})$ \\
\cline { 2 - 3 } & A260/A230 & A260/A280 & \\
\hline RNAiso Plus & $1.12 \pm 0.07$ & $1.72 \pm 0.06$ & $201.77 \pm 36.78$ \\
RNAiso Plus+RNAiso-mate & $2.13 \pm 0.36$ & $1.80 \pm 0.12$ & $215.20 \pm 79.94$ \\
Trizol & $0.57 \pm 0.23$ & $1.57 \pm 0.13$ & $31.66 \pm 15.45$ \\
Qi method & 5.5 & 1.83 & 8.65 \\
\hline
\end{tabular}

Data are reported as means \pm SD from more than six independent RNA extraction replicas for each method, except for the Qi method. RNAiso Plus+RNAiso-mate: RNAiso Plus+RNAiso-mate for Plant Tissue (TaKaRa).

According to the modified method, it seemed that the addition of different volumes of absolute ethanol in extraction buffer could affect the purity and yield of the RNA extracted. When 200 or $350 \mu \mathrm{L}$ absolute ethanol was used in the modified method, only low purity and yield of total RNA was obtained (Table 2). In the other three modified methods, the total RNA obtained was of high quality and purity, while the yield by adding $250 \mu \mathrm{L}$ absolute ethanol was higher than those methods by adding more or lower than $250 \mu \mathrm{L}$ ethanol. 
Table 2. Purity and yield of the total RNA extracted from seeds of sunflower by the modified method using different volumes of absolute ethanol.

\begin{tabular}{cccc}
\hline Ethanol $(\mu \mathrm{L})$ & \multicolumn{2}{c}{ Purity } & Yield $(\mu \mathrm{g} / 100 \mathrm{mg})$ \\
\cline { 2 - 3 } & A260/A230 & A260/A280 & \\
\hline 0 & $2.61 \pm 0.90$ & $1.94 \pm 0.15$ & $20.39 \pm 8.05$ \\
150 & $2.64 \pm 0.52$ & $1.99 \pm 0.34$ & $21.87 \pm 7.60$ \\
200 & $1.04 \pm 0.26$ & $1.21 \pm 0.54$ & $3.20 \pm 0.54$ \\
250 & $2.44 \pm 0.23$ & $2.09 \pm 0.16$ & $29.95 \pm 8.21$ \\
350 & $1.36 \pm 0.97$ & $1.50 \pm 0.87$ & $1.71 \pm 1.26$ \\
\hline
\end{tabular}

Data are reported as means \pm SD from more than eight independent RNA extraction replicas for each volume of ethanol.

\section{Integrity of the total RNA}

When analyzing the total RNA obtained by $1 \%$ agarose gel electrophoresis with GreenView staining, three bands of RNA, 28S, 18S and 5S ribosomal RNA, could only be found in RNA from modified methods based on the Qi method (Figure 1), while only one band or smear RNA was tested in RNA extracted by RNAiso Plus, RNAiso Plus+RNAiso-mate for Plant Tissue, Trizol, or the Qi method. In modified methods, genomic DNA was contained in the total RNA extracted, when $0 \mu \mathrm{L}$ or $350 \mu \mathrm{L}$ absolute ethanol was used in extraction buffer, while the contaminant DNA in the RNA extracted without ethanol treatment was higher than that by $350 \mu \mathrm{L}$ ethanol. In the modified method by adding $200 \mu \mathrm{L}$ ethanol, inadequate brightness of RNA could be viewed on agarose gel, suggesting its low yield of RNA. By comparing the bands by modified methods with 150 or $250 \mu \mathrm{L}$ ethanol, the amount of $28 \mathrm{~S}$ RNA was more than 2-fold that of $18 \mathrm{~S}$ RNA by the method with $250 \mu \mathrm{L}$ ethanol, while the amounts of the two bands were nearly equal, indicating that the method by adding $250 \mu \mathrm{L}$ ethanol for modification was most suitable for further study.
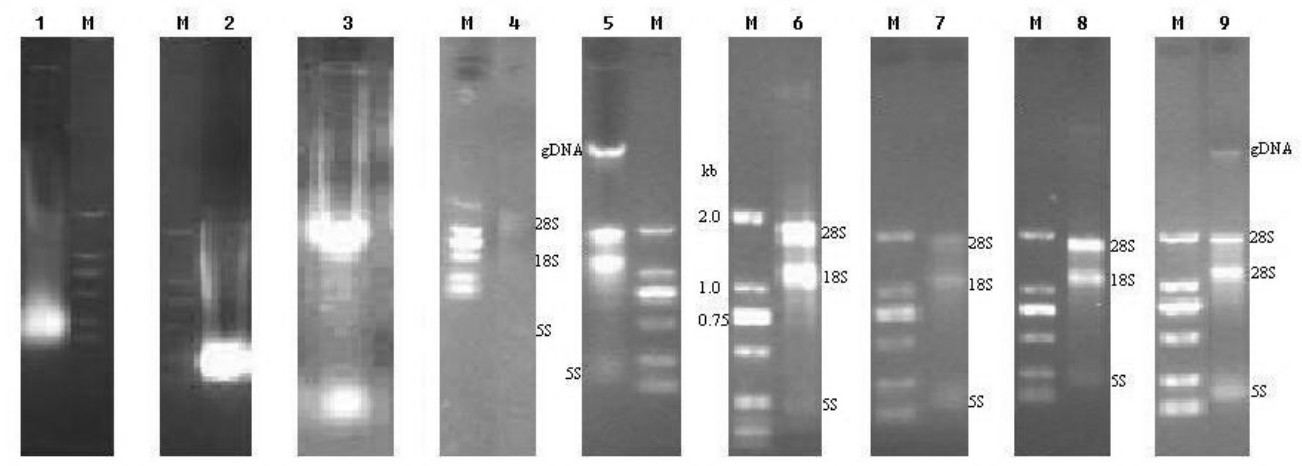

Figure 1. Total RNA by 1.0\% agarose gel electrophoresis extracted from seeds of sunflower by kits, Qi method, and the modified method via adding different volume of absolute ethanol. Lane $1=$ RNAiso Plus; lane 2 = RNAiso Plus + RNAiso-mate for Plant Tissue; lane $3=$ Trizol; lane $4=$ Qi method; lane $5=0 \mu \mathrm{L}$; lane $6=150 \mu \mathrm{L}$; lane $7=$ $200 \mu \mathrm{L}$; lane $8=250 \mu \mathrm{L}$; lane $9=350 \mu \mathrm{L} ; \mathrm{M}=$ marker DL2000. 


\section{RT-PCR analysis}

To further evaluate the integrity of the RNA extracted by the modified method adding $250 \mu \mathrm{L}$ ethanol, the RNA obtained was used to amplify the housekeep gene, actin, by RT-PCR. The results showed that a fragment of about $1.1 \mathrm{~kb}$ was amplified (Figure 2 ). Sequence analysis indicated that this fragment has high similarity with actin genes in other species.

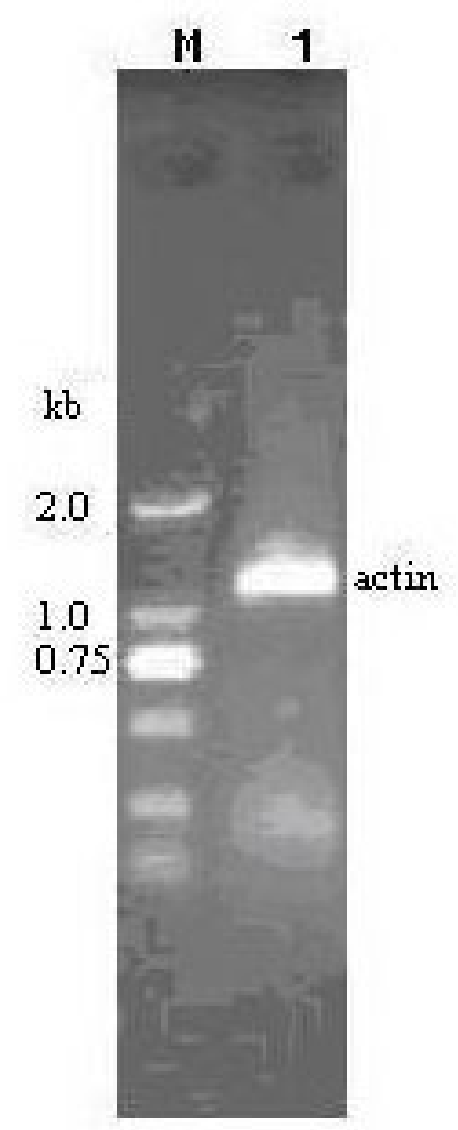

Figure 2. A fragment of actin gene on 1.0\% agarose gel electrophoresis amplified by RT-PCR. Lane $1=$ fragment of actin gene with about $1.1 \mathrm{~kb} ; \mathrm{M}=$ marker DL2000.

\section{DISCUSSION}

Following illustrations of the three kits, RNAiso Plus, RNAiso Plus+RNAiso-mate for Plant Tissue, and Trizol, we tried our best to isolate total RNA from seeds for the use of gene cloning and to investigate the molecular mechanism of mutation induced by space flight. The results showed that only low purity of total RNA was obtained by the original directions of RNAiso Plus or Trizol. In contrast, the total RNA extracted by the RNAiso Plus+RNAiso-mate 
for Plant Tissue method was of high purity and high yield, but still not suitable for further study, because the RNA showed low integrity by electrophoretic analysis. According to the steps described by Qi et al. (2009), the lower yield of total RNA was harvested from dry seeds free of seedcase, furthermore the RNA obtained was degraded to some extent through electrophoretic test, so this method could not be used to isolate total RNA from sunflower seeds directly.

More impurities were included in mature seeds than in other tissues, such as polyphenol, polysaccharide, secondary metabolites, which are known to co-isolate with nucleic acids from plant tissues resulting in inhibition of molecular manipulations (Koonjul et al., 1999), and protein, which could affect total RNA extraction (Birtic and Kranner, 2006). According to previous reports (Qi et al., 2009; Ghangal et al., 2009; Bilgin et al., 2009), PVP, $\beta$-mercaptoethanol, and absolute ethanol are absolutely necessary to eliminate this impurities. Thus, these chemicals were used to modify the method by Qi et al. (2009) to test their effects on RNA isolation from sunflower seeds.

In order to eliminate the high level of storage polyphenolics in dry seeds, which can reduce the yield and purity of extracted RNA via powerful oxidizing, the following measures were taken during the procedure of RNA extraction. The first measure was added proper amount of PVP to the mortar and altogether pestled with the dry seeds free of seedcase, to prevent the oxidation of polyphenolics of grinded samples in long air exposure. Then $2 \%$ PVP30 and 5\% $\beta$-mercaptoethanol, without cysteine in the modified method, were applied in the extraction buffer for extracting RNA from homogenate fractured cell powders. This step is reasonably critical to inhibit the oxidation of polyphenolics, and 5\% $\beta$-mercaptoethanol was enough to function. The third measure was to extract homogenate with chloroform prior to phenol-chloroform extraction to prevent contamination by polyphenolics (Suzuki et al., 2004; Onate-Sanchez and Vicente-Carbajosa, 2008). The improved measures above played an important role on avoiding polyphenolics oxidizing when obtaining high-quality RNA.

Another impurity was high content of storage polysaccharide in dry seeds, which could make extraction buffer thicker after adding sample and some impurities flow down difficultly. So, the addition of absolute ethanol was able to precipitate polysaccharide and other impurities in extraction buffer (Qi et al., 2009). In our modified method, RNA was precipitated from the upper clear phase by using $1 / 4$ volume of $3 \mathrm{M}$ sodium acetate and 2 volumes of absolute ethanol at the final procedure, which was reported to eliminate polysaccharide contamination by increasing the sodium acetate content (Singh et al., 2003; Suzuki et al., 2004; Wang et al., 2005).

To prevent the contamination of proteins, the addition of equal volume NaAc-saturated acidic phenol, $\mathrm{pH} 4.5$, and $300 \mu \mathrm{L}$ chloroform to supernatant, substituting for equal volume Tris-saturated phenol, $\mathrm{pH} 7.8$, phenol:chloroform:isoamyl alcohol (25:24:1), prior to centrifugation, could effectively make proteins denatured, and beneficial for elimination of the protein contamination. To be mentioned, in the acidic conditions for eliminating protein, DNA of smaller or larger fragments was readily dissolved in the acidic phenol or collected at the interphase during centrifugation, and the chloroform could separate liquid phase from organic phase (Mulhardt, 2007). Meanwhile, the means for removing protein were efficacious to inhibit the nuclease to keep RNA from degradation. According to previous reports, the presence of $\beta$-mercaptoethanol and the use of high salt concentration in the extraction buffer ( $8 \mathrm{M}$ $\mathrm{LiCl}$ ) inhibited nuclease activity (Vicient and Delseny, 1999).

Comparatively, it is more difficult to grind the materials into powders from plant than those from animal, due to the rigid cell walls in plant that need to be degraded in order to ex- 
pose internal nucleic acids (Wang and Stegemann, 2009). So the materials were pre-frozen in liquid nitrogen $\left(\mathrm{LN}_{2}\right)$ for a minimum of 20 min up to overnight, and then be ground in the presence of liquid nitrogen. The results showed that the pretreatment was benefit for fine powder formation. To prevent interference of the cell wall to the greatest extent, the seedcases were wiped off from the mature seed, and the remained parts were left for RNA extraction.

Via the modifications mentioned above, high-quality total RNA was extracted, with high yield and integrity, by spectrophotometric and electronphoretic analysis, comparing with previous methods. Furthermore, this was confirmed by amplifying actin gene fragment by RTPCR. Thus, the modified method was suitable for isolate high-quality total RNA from mature seeds of sunflower and beneficial for further study to investigate the molecular mechanism of mutation induced by space flight.

\section{ACKNOWLEDGMENTS}

Research supported by the Sichuan Provincial Youth Science and Technology Foundation (\#05ZQ026-017), and Sichuan Provincial Key Subject Programme (\#SZD0420), P. R. China.

\section{REFERENCES}

Alonso AP, Goffman FD, Ohlrogge JB and Shachar-Hill Y (2007). Carbon conversion efficiency and central metabolic fluxes in developing sunflower (Helianthus annuus L.) embryos. Plant J. 52: 296-308.

Azevedo H, Lino-Neto T and Tavares RM (2003). An improved method for high-quality RNA isolation from needles of adult maritime pine trees. Plant Mol. Biol. Rep. 21: 333-338.

Bilgin DD, DeLucia EH and Clough SJ (2009). A robust plant RNA isolation method suitable for Affymetrix GeneChip analysis and quantitative real-time RT-PCR. Nat. Protoc. 4: 333-340.

Birtic S and Kranner I (2006). Isolation of high-quality RNA from polyphenol-, polysaccharide- and lipid-rich seeds. Phytochem. Anal. 17: 144-148.

Ghangal R, Raghuvanshi S and Chand SP (2009). Isolation of good quality RNA from a medicinal plant seabuckthorn, rich in secondary metabolites. Plant Physiol. Biochem. 47: 1113-1115.

Huaiqin Z, Jianshe W, Shilin C, Yuanquan C, et al. (2009). Genetic diversity analysis of ornamental sunflower germplasm resources with RAPD. Mol. Plant Breed. 7: 73-78.

Koonjul PK, Brandt WF, Farrant JM and Lindsey GG (1999). Inclusion of polyvinylpyrrolidone in the polymerase chain reaction reverses the inhibitory effects of polyphenolic contamination of RNA. Nucleic Acids Res. 27: 915-916.

$\mathrm{Li} \mathrm{Z}$ and Trick HN (2005). Rapid method for high-quality RNA isolation from seed endosperm containing high levels of starch. Biotechniques 38: 872-876.

Mulhardt C (Editors) (2007). Molecular Biology and Genomics. Academic Press, London, 95-98.

Onate-Sanchez L and Vicente-Carbajosa J (2008). DNA-free RNA isolation protocols for Arabidopsis thaliana, including seeds and siliques. BMC Res. Notes 1: 92.

Qi G, Li JT, Ruan QP, Yang J, et al. (2009). An optimised, small-scale preparation of high-quality RNA from dry seeds of Davidia involucrata. Phytochem. Anal. 20: 139-142.

Ruiz-Lopez N, Garces R, Harwood JL and Martinez-Force E (2010). Characterization and partial purification of acylCoA:glycerol 3-phosphate acyltransferase from sunflower (Helianthus annuus L.) developing seeds. Plant Physiol. Biochem. 48: 73-80.

Salzman RA, Fujita T, Zhu-Salzman K, Hasegawa PM, et al. (1999). An improved RNA isolation method for plant tissues containing high levels of phenolic compounds or carbohydrates. Plant Mol. Biol. Rep. 17: 11-17.

Singh G, Kumar S and Singh P (2003). A quick method to isolate RNA from wheat and other carbohydrate-rich seeds. Plant Mol. Biol. Rep. 21: 93a-93f.

Suzuki Y, Kawazu T and Koyama H (2004). RNA isolation from siliques, dry seeds, and other tissues of Arabidopsis thaliana. Biotechniques 37: 542-544.

Vicient CM and Delseny M (1999). Isolation of total RNA from Arabidopsis thaliana seeds. Anal. Biochem. 268: 412-413.

Wang L and Stegemann JP (2009). Extraction of high quality RNA from polysaccharide matrices using cetyltrimethylam- 
monium bromide. Biomaterials 31: 1612-1618

Wang T, Zhang N and Du L (2005). Isolation of RNA of high quality and yield from Ginkgo biloba leaves. Biotechnol. Lett. 27: 629-633.

Zavallo D, Lopez BM, Hopp HE and Heinz R (2010). Isolation and functional characterization of two novel seed-specific promoters from sunflower (Helianthus annuus L.). Plant Cell Rep. 29: 239-248. 